\title{
Relationships between morphology, diet and spatial distribution: testing the effects of intra and interspecific morphological variations on the patterns of resource use in two Neotropical Cichlids
}

\author{
Ana Lúcia A. Sampaio ${ }^{1}$, João Paulo A. Pagotto ${ }^{1}$ and Erivelto Goulart ${ }^{1,2}$
}

Considering the morphology, diet and spatial distribution of Satanoperca pappaterra and Crenicichla britskii (Perciformes: Cichlidae) in the Upper Paraná River floodplain (Brazil), the following questions were investigated: (1) Could the body shape predict the use of trophic resources and habitat by C. britskii and S. pappaterra? (2) Could the relationship between morphology and use of trophic resources and habitat be also extended to the intraspecific scale? (3) What are the most important morphological traits used to predict the variation on diet and habitat occupation within and between species? We hypothesized that intra and interspecific differences in morphological patterns imply in different forms of resource exploitation and that the ecomorphological analysis enables the identification of trophic and spatial niche segregation. Fish samplings were performed in different types of habitats (rivers, secondary channels, connected and disconnected lagoons) in the Upper Paraná River floodplain. Analyses of the stomach content was conducted to characterize the feeding patterns and twenty-two ecomorphological indices were calculated from linear morphological measurements and areas. A principal component analysis (PCA) run with these indices evidenced the formation of two significant axes, revealing in the axis 1 an ecomorphological ordination according to the type of habitat, regardless the species. The individuals of both species exploiting lotic habitats tended to have morphological traits that enable rapid progressive and retrograde movements, braking and continuous swimming, whereas individuals found in lentic and semi-lotic habitats presented morphology adapted to a greater maneuverability and stabilization in deflections. On the other hand the axis 2 evidenced a segregation related to the feeding ecology, between S. pappaterra and C. britskii. The relationship between morphology and use of spatial and feeding resource was corroborated by the Mantel test performed at inter and intraspecific levels. Therefore the hypothesis was accepted suggesting that analyses incorporating both intraspecific and interspecific morphological variations can contribute to a greater understanding about the ecological structure of fish assemblages by providing evidences on the niche characteristics of each species.

Considerando a morfologia, a dieta e a distribuição espacial de Satanoperca pappaterra e Crenicichla britskii (Perciformes: Cichlidae) na planície de inundação do alto rio Paraná (Brasil) as seguintes questões foram investigadas: (1) A forma do corpo pode ser utilizada para predizer o uso dos recursos espaciais e tróficos por ambas as espécies? (2) As relações entre morfologia e uso dos recursos tróficos e espaciais podem ser estendidas à escala intraespecífica? (3) Quais são as características morfológicas utilizadas para predizer a variação na dieta e ocupação do hábitat em nível intra e interespecífico? Testou-se a hipótese de que diferenças intra e interespecíficas nos padrões morfológicos implicam em diferentes formas de exploração dos recursos, sendo que a partir de análises ecomorfológicas é possível identificar a segregação do nicho trófico e espacial. Os peixes foram amostrados em diferentes tipos de hábitats (rios, canais secundários, lagoas conectadas e desconectadas) na planície de inundação do alto rio Paraná. Análises de conteúdo estomacal foram realizadas a fim de caracterizar os padrões alimentares, enquanto vinte e dois índices ecomorfológicos foram calculados com base nas medidas morfométricas lineares e áreas. A análise de componentes principais (PCA) realizada com os referidos índices evidenciou a formação de dois eixos significativos: no eixo 1 houve uma ordenação ecomorfológica de acordo com o tipo de hábitat explorado, independentemente da espécie considerada. Nesse sentido, indivíduos de ambas as espécies coletados em ambientes lóticos tenderam a apresentar características morfológicas que

${ }^{1}$ Universidade Estadual de Maringá (UEM), Programa de Pós-Graduação em Ecologia de Ambientes Aquáticos Continentais (PEA). Av. Colombo, no 5790, Bloco G-90,87020-900 Maringá, PR, Brazil. analucia_antunes@yahoo.com.br (ALAS); pagotto.jpa@gmail.com (JPAP)

${ }^{2}$ Universidade Estadual de Maringá (UEM), Núcleo de Pesquisas em Limnologia, Ictiologia e Aquicultura (NUPÉLIA). Av. Colombo, n ${ }^{\circ}$ 5790, Blocos G-90 e H-90, 87020-900 Maringá, PR, Brazil. goulart@nupelia.uem.br 
propiciam maior capacidade de movimentos progressivos e retrógrados, frenagens e natação contínua, enquanto os indivíduos encontrados em ambientes lênticos e semi-lóticos apresentaram morfologia adaptada à maior capacidade de manobrabilidade e estabilização em guinadas. Por outro lado, o eixo 2 evidenciou segregação ecomorfológica relacionada à dieta, revelando uma divergência entre S. pappaterra e C. britskii. Essa relação entre morfologia e uso dos recursos espacial e alimentar foi confirmada pela significância do teste de Mantel realizado em nível intra e interespecífico. Portanto, a hipótese pressuposta foi aceita, sugerindo que análises que incorporam variações morfológicas intra e interespecíficas podem contribuir para o maior entendimento sobre a estrutura das assembleias de peixes, propiciando evidências acerca das características do nicho de cada espécie.

Key words: Crenicichla britskii, Ecomorphology, Ecomorphotype, Satanoperca pappaterra, Upper Paraná River floodplain.

\section{Introduction}

Ecomorphology is a branch of environmental sciences that deals with relationships between morphology and variations in the resource use in individuals, populations, guilds and assemblages (Peres-Neto, 1999; Oliveira et al., 2010). Ecomorphological studies seek to understand how organisms respond to environmental pressures, and may reveal patterns of association between body shape and the resources use (Gatz Jr., 1979; Wikramanayake, 1990; Ricklefs \& Miles, 1994; Motta et al., 1995; Wainwright \& Richard, 1995; Delariva \& Agostinho, 2001; Freire \& Agostinho, 2001; Xie et al., 2001; Casatti \& Castro, 2006; Oliveira et al., 2010).

Cichlids comprise a group of fish widely distributed throughout the Neotropical regions and have singular morphological characteristics that allow them to live under diverse environmental conditions (Lowe-McConnell, 1991; Meyer, 1993). Some authors have reported correlations between body shape, diet and habitat among Cichlid species, where differences in morphology were used to explain differences in the exploitation of trophic and spatial resources (Norton \& Brainerd, 1993; Norton, 1995; Winemiller, et al. 1995; Montaña \& Winemiller, 2009). These studies analyzed the distribution of species in the interspecific multivariate ecomorphological space and argued that some patterns may be related to the evolutionary convergence or divergence of the body shape. Likewise, intraspecific ecomorphological approaches in Cichlids have evidenced that differences in feeding apparatus within the same population facilitate resource partitioning and reduce the competition (Swanson et al., 2003).

Despite these close relationships previously reported, associations between body shape and resource use are not ubiquitous (Douglas \& Matthews, 1992) and instances of ecomorphological mismatch have been documented at inter and intraspecific level (Binning \& Chapman, 2010; Griffen \& Mosblack, 2011). Therefore ecomorphological analyses performed with sympatric and closely related species or even at the intraspecific level are important to test the role of morphology to predict ecology and may allow identifying adaptive ecomorphological patterns set by the selection process (Douglas \& Matthews, 1992; Mittelbach et al., 1992), as well as to determine the main functional morphological traits used to explore the trophic and spatial niche (Delariva \& Agostinho, 2001; Pagotto et al., 2011).

Crenicichla britskii Kullander, 1982 and Satanoperca pappaterra (Heckel, 1840) are two sympatric cichlid species; the first is endemic to the Upper Paraná River basin and the latter is widely distributed across some hydrographic basin in South America (Agostinho et al., 2004; Castro et al., 2004; Graça \& Pavanelli, 2007). The singular trophic apparatus and body shape of these species may be one of the main characteristics responsible for explaining their successful colonization in aquatic ecosystems (Kullander, 2003; Sampaio \& Goulart, 2011). Considering the morphology, diet and spatial distribution of these species in the Upper Paraná River floodplain, the following questions were investigated: (1) Could the body shape predict the use of trophic resources and habitat by C. britskii and S. pappaterra? (2) Could the relationship between morphology and use of trophic resources and habitat be also extended to the intraspecific scale? (3) What are the most important morphological traits used to predict the variation on diet and habitat occupation within and between species? We hypothesized that intra and interspecific differences in morphological patterns imply in different forms of resource exploitation and that the ecomorphological analysis enables the identification of trophic and spatial niche segregation.

\section{Material and Methods}

Study area. The Paraná River is the second largest river of South America and the largest of the La Plata River basin, with more than 4,000 km length, 2.8 million $\mathrm{km}^{2}$ of catchment area and 500 million $\mathrm{m}^{3}$ of annual discharge with peak flows of $65,000 \mathrm{~m}^{3} \mathrm{~s}^{-1}$ (Maack, 1981; Bonetto, 1986). The study area covered the floodplain located in the third lower stretch of the upper Paraná River.

This floodplain is situated in the upper part of the Environmental Protection Area of Islands and Wetlands of the Paraná River, comprising the last dam-free stretch of the Paraná River in Brazilian territory, characterized by a meandering system containing lotic environments (rivers), semi-lotic (secondary channels s) and lentic (connected and disconnected lagoons), whose characteristics are listed in Table 1. Samplings were conducted at 36 sampling sites 
Table 1. Description of the sampled environments.

\begin{tabular}{cl}
\hline Environments & \multicolumn{1}{c}{ Characteristics } \\
\hline Rivers & $\begin{array}{l}\text { Lotic environments characterized by high mean current velocity, close to 1 m/s, variable } \\
\text { according to the flow. }\end{array}$ \\
\hline \multirow{3}{*}{ Connected Lagoons } & $\begin{array}{l}\text { Lentic environments continuously connected with rivers or channels. They are slightly } \\
\text { rounded and without well-defined boundaries because gradually become flooded areas. } \\
\text { Depth ranges from } 1.5 \text { to } 5 \mathrm{~m} \text {. This category includes backwaters, lentic environments } \\
\text { resulting from the margins of the sidebars to the islands of the Paraná River. }\end{array}$ \\
\hline \multirow{2}{*}{ Disconnected Lagoons } & $\begin{array}{l}\text { Lentic environments that occupy the most depressed areas of the floodplain, without } \\
\text { direct connection with rivers or channels. Intense sedimentation with predominance of } \\
\text { mud and organic matter. }\end{array}$ \\
\hline \multirow{2}{*}{ Secondary Channels } & $\begin{array}{l}\text { Semi-lotic environments with reduced velocity, with possibility of change in the direction } \\
\text { of the water current. Quite varied characteristics of length, width, average depth and } \\
\text { vegetation on the banks. Generally, a channel connects at least two environments, but can } \\
\text { also connect two points of the same environment. }\end{array}$ \\
\hline
\end{tabular}

along these different types of habitats, belonging to the sub-basins of the rivers Paraná, Baía and Ivinhema.

Data collection. Samplings were performed in June, September, December 2009, and March and June 2010 in the different habitats of the Upper Paraná River floodplain (Table 1). Fish were captured by gill nets of different mesh sizes (2.4, $3,4,5,6,7,8,10,12,14$ and $16 \mathrm{~cm}$ ) exposed for 24 hours, and inspected every eight hours. Samplings were carried out through the Long Term Ecological Research (PELD - site 6). The captured individuals were taken to the field laboratory of the Núcleo de Pesquisas em Limnologia, Ictiologia e Aquicultura (Nupélia), Universidade Estadual de Maringá (UEM), located in Porto Rico city, Paraná State, Brazil, where they were numbered, measured and weighed. The species identification was undertaken according to Graça \& Pavanelli (2007). Voucher specimens of S. pappaterra (NUP 12349) and C. britskii (NUP 12350, NUP 12351) were deposited in the Ichthyological Collection of Nupélia, http:// peixe.nupelia.uem.br/.

Diet analysis. Fish were gutted and stomachs were fixed in $4 \%$ formaldehyde, and later preserved in alcohol $70^{\circ} \mathrm{GL}$. Seventy stomachs of $S$. pappaterra and 17 of $C$. britskii were used to characterize the trophic ecology of these species. Stomach content analyses were performed under a stereomicroscope and an optical microscope whenever needed.

The diet analysis was performed by the occurrence method (percentage of stomachs containing each item in relation to the total of occurrences) and volumetric method, by which it was estimated, in percentage, the volume of each food item in relation to the volume present in all stomachs (Hyslop, 1980). Thus, the volume was quantified using grid Petri dishes, on which the food items were compressed with glass slides until $1 \mathrm{~mm}$ height. The number of quadrants occupied by each food item on the dish was multiplied by 0.001 to obtain the volumes in $\mathrm{mm}^{3}$ (Hellawell \& Abel, 1971). Given the absence of food in the stomach of many individuals, it was also analyzed the content of the first third of the intestine, but, for practical purposes, these were treated together, and referred to as stomach contents.

The food resources were grouped into nine categories: detritus, higher plant, algae, crustacean, aquatic insect, terrestrial invertebrate, mollusk, other aquatic invertebrate, and fish. To characterize the trophic patterns of each species, the volumetric and occurrence data of the items were combined in the Alimentary Index (IAi) (Kawakami \& Vazzoler, 1980), expressed by:

$$
I A i=\frac{O_{i} V_{i}}{\sum_{i=1}^{n}\left(O_{i} V_{i}\right)} \times 100
$$

where: $i=$ food item; $O=$ frequency of occurrence $(\%)$ of item $i$ in the diet; $V=$ volume (\%) of item $i$ in the diet.

Ecomorphological analysis. Nineteen linear morphometric measurements and six areas were taken (Table 2; see Oliveira et al., 2010 for further detail) from 89 individuals, 66 S. pappaterra and 23 C. britskii. Linear measurements up to $150 \mathrm{~mm}$ were taken with a digital caliper accurate to $0.01 \mathrm{~mm}$, and larger measurements, using a metal ruler accurate to $1.0 \mathrm{~mm}$. The areas of eyes and fins were obtained by drawing the contour of the structures in plastic sheets that were then digitized for the calculation of the areas using the software AutoCAD ${ }^{\circledR}$ (Autodesk, 2004). The measurements were taken from the left side of the specimens. The collection of morphometric data was performed with newly caught fish to minimize the effect of preservative substances on the morphometric variability (Peterson \& VanderKooy, 1996). To reduce the influence of ontogenetic variation on the ecomorphological data, only adult individuals were used. In order to reduce the dimensionality of the variables, linear morphometric measurements were transformed, using the logarithm function as a parameter for standardization. Ecomorphological indices were calculated from these linear morphometric measurements and areas (Table 2), which expressed the shapes of morphological structures and hence reveal their ecological roles (Gatz Jr., 1979; Winemiller, 1991).

Data analysis. A principal component analysis (PCA) was applied on the covariance matrix formed by 22 ecomorphological indices for both species, aiming to summarize the multivariate morphological space into few dimensions that could better explain the organization of the 
Table 2. Ecomorphological indices with respective formulas and biological interpretations. Formulas include the following measurements: standard length (SL), maximum body height (MBH), body midline height (BMH), maximum body width (MBW), caudal peduncle length $(\mathrm{CPdL})$, caudal peduncle height $(\mathrm{CPdH})$, caudal peduncle width $(\mathrm{CPdW})$, head length (HdL), head height ( $\mathrm{HdH})$, head width (HdW), length of snout with the mouth closed (LSC), length of snout with the mouth open (LSO), eye height $(\mathrm{EH})$, mouth height $(\mathrm{MH})$, mouth width $(\mathrm{MW})$, caudal fin height $(\mathrm{CH})$, anal fin length (AL), pectoral fin length (PtL), pelvic fin length $(\mathrm{PvL})$, eye area (EA), dorsal fin area (DA), caudal fin area (CA), anal fin area (AA), pectoral fin area (PtA), pelvic fin area (PvA).

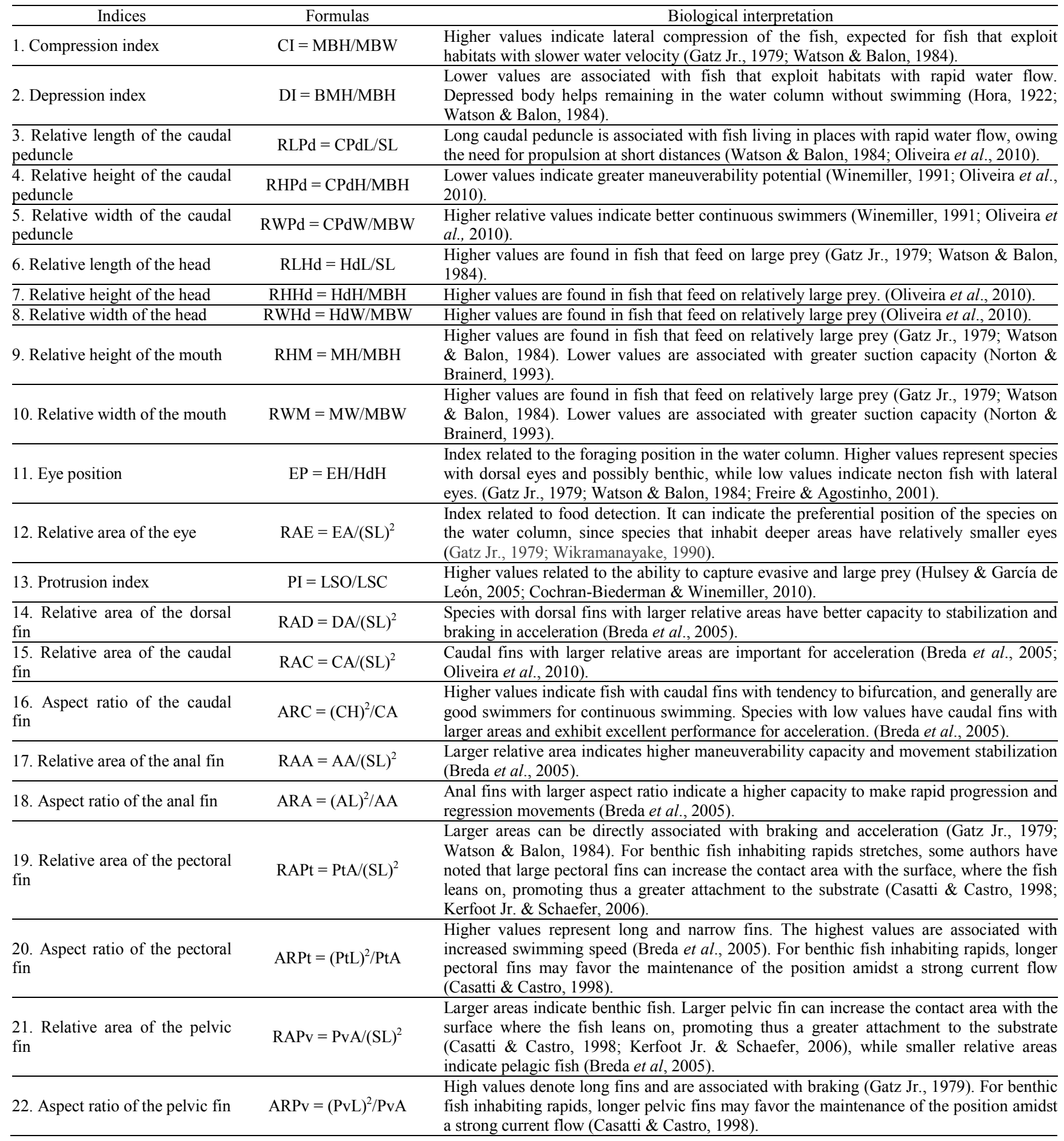


original data set (Peres-Neto, 1999). To select the significant axes in the PCA, the broken-stick criterion was used (Jackson, 1993), in which the axes with eigenvalues higher than those generated at random were retained for interpretation. The scores were characterized according to the species type, the habitat where each individual fish was collected and the food resource type preferably exploited by each individual. A Multi-Response Permutation Procedure (MRPP) was employed for checking possible ecomorphological differences in the multivariate space occupied by these groups of scores. A Monte Carlo procedure with 10,000 randomizations was used to test the null hypothesis that the occupation of the ecomorphological space is not significantly different.

Mantel tests correlating the matrix of morphological distance with the matrix of trophic and spatial distance were performed for each species separately and also for both species together, in order to investigate whether higher similarity (smaller morphological distance) is related to the use of similar feeding resources (smaller trophic distance) and occupation of the same type of habitat (same spatial distance), at intra and interspecific level respectively. These tests were carried out through the Monte Carlo randomization procedure with 10,000 permutations, with the purpose to test the null hypothesis of no association between trophic, spatial and morphological patterns. The Mantel test was performed with 71 individuals, 58 S. pappaterra and $13 C$. britskii.

The morphologic distance was obtained from the Euclidean distances between the ecomorphological indices for each pair of individuals, according to Gotelli \& Ellison (2004). The trophic distance was obtained from the Bray-Curtis distance between the volume of the food item for each pair of individuals, ranging from 0 (maximum similarity) to 1 (maximum dissimilarity), according to Valentin (1995).

The matrix of spatial distance was obtained by assigning the value 1 to the pair of individuals from the same habitat and 0 to the pair of individuals that had not satisfied this condition. The ordination analyses (PCA), the MRPP, the calculation of trophic distance and morphological and Mantel test were performed using the software PC-Ord ${ }^{\circledR} 5.0$ (McCune \& Mefford, 1999).

\section{Results}

Diet. In Table 3 are listed the food items that comprised the diet of both species, with respective volumes (V) and occurrences $(\mathrm{O})$, in percentage, and also the alimentary index for each species, calculated for trophic categories, expressed in percentage. This index revealed that $S$. pappaterra primarily consumed detritus (IAi $=76.13 \%$ ), whereas C. britskii consumed mostly fish (scale, fin, and others fragments of fish $)(\mathrm{IAi}=50.00 \%)$ and crustacean $(\mathrm{IAi}=19.03 \%)$.

Ecomorphological analysis. The PCA evidenced the formation of two significant axes, according to the broken-stick model,
Table 3. Diet composition and alimentary index of Satanoperca pappaterra and Crenicichla britskii in the Upper Paraná River floodplain $(\% \mathrm{~V}=$ percentage of volume; $\% \mathrm{O}=$ percentage of occurrence and $\mathrm{IA} \mathrm{i}=$ alimentary index; $\mathrm{NI}=$ non-identified).

\begin{tabular}{|c|c|c|c|c|c|}
\hline \multirow[b]{2}{*}{ Items } & \multicolumn{3}{|c|}{$\begin{array}{l}\text { Satanoperca } \\
\text { pappaterra }\end{array}$} & \multicolumn{2}{|c|}{ Crenicichla britskii } \\
\hline & $\% \mathrm{~V}$ & $\% \mathrm{O}$ & $\operatorname{IAi}(\%)$ & $\% \mathrm{~V}$ & $\% \mathrm{O}$ IAi $(\%)$ \\
\hline Detritus (Det) & 70.03 & 98.57 & 76.13 & 21.41 & 29.4117 .77 \\
\hline Higher plant (Hig) & 9.69 & 80.00 & 8.55 & 4.44 & 52.946 .63 \\
\hline Algae (Alg) & & & 0.91 & & 0.62 \\
\hline Cyanophyceae & 0.05 & 15.71 & & 0.01 & 5.88 \\
\hline Chlorophyceae & 0.07 & 15.71 & & 0.11 & 11.76 \\
\hline Bacillariophyceae & 0.59 & 72.86 & & 0.16 & 17.65 \\
\hline Euglenophyceae & 0.00 & 2.86 & & 0.15 & 5.88 \\
\hline Oedogoniophyceae & 0.11 & 14.29 & & 0.21 & 11.76 \\
\hline Zygnemaphyceae & 0.27 & 22.86 & & 0.29 & 17.65 \\
\hline Crustacean $(\mathrm{Cru})$ & & & 9.13 & & 19.03 \\
\hline Copepoda & 2.89 & 84.29 & & 0.57 & 5.88 \\
\hline Cladocera & 2.15 & 78.57 & & 0.21 & 11.76 \\
\hline Ostracoda & 3.86 & 60.00 & & 0.06 & 5.88 \\
\hline Decapoda & - & - & & 22.09 & 5.88 \\
\hline Aquatic insect (Aqu) & & & 2.58 & & 2.45 \\
\hline Diptera & 0.02 & 5.71 & & - & - \\
\hline Simuliidae & $<0.01$ & 1.43 & & - & - \\
\hline Ceratopogonidae & 0.09 & 10.00 & & - & - \\
\hline Chironomidae & 2.47 & 64.29 & & 0.10 & 23.53 \\
\hline Trichoptera & 0.14 & 2.86 & & 0.38 & 5.88 \\
\hline Coleoptera & 0.54 & 2.86 & & - & - \\
\hline Odonata & 0.34 & 2.86 & & - & - \\
\hline Ephemeroptera & 0.02 & 2.86 & & 1.37 & 29.41 \\
\hline Terrestrial invertebrate (Ter) & & & 0.01 & & 0.11 \\
\hline Insect fragments - NI & 0.01 & 4.29 & & 0.13 & 5.88 \\
\hline Hymenoptera & - & - & & 0.19 & 5.88 \\
\hline Hemiptera & 0.11 & 4.29 & & - & - \\
\hline Acari & 0.05 & 7.14 & & - & - \\
\hline Adult Diptera & 0.03 & 1.43 & & - & - \\
\hline Mollusk (Mol) & & & 1.98 & & 3.04 \\
\hline Bivalvia & 4.53 & 37.14 & & 3.62 & 23.53 \\
\hline Gastropoda & 0.12 & 4.29 & & 0.95 & 5.88 \\
\hline $\begin{array}{l}\text { Other aquatic invertebrate } \\
\text { (Oth) }\end{array}$ & & & 0.28 & & 0.35 \\
\hline Nematoda & 0.26 & 31.43 & & 0.44 & 17.65 \\
\hline Rotifera & $<0.01$ & 1.43 & & - & - \\
\hline Testate amoebae & 0.01 & 4.29 & & 0.10 & 5.88 \\
\hline Sponge spicules & 0.01 & 8.57 & & - & - \\
\hline Oligochaeta & 0.15 & 17.14 & & - & - \\
\hline Tardigrada & $<0.01$ & 1.43 & & - & - \\
\hline Hidracarina & 0.08 & 4.29 & & - & - \\
\hline Fish (Fis) & & & 0.43 & & 50.00 \\
\hline Scale & 1.27 & 30.00 & & 1.68 & 29.41 \\
\hline Fin & 0.03 & 1.43 & & 17.25 & 11.76 \\
\hline Fragments - NI & - & - & & 24.09 & 11.76 \\
\hline Number of stomachs & & 70 & & & 17 \\
\hline
\end{tabular}

and explained $74.19 \%$ total data variability (Table 4 ). The axis 1 revealed an ecomorphological ordination according to the type of habitat and the MRPP indicated that the ecomorphological patterns in each habitat type was significantly different $(A=0.037 ; p<0.01)$. The individuals exploiting lotic habitats tended to have positive scores and showed higher values of the aspect ratio of the anal, pelvic, pectoral and caudal fins (ARA, ARPv, ARPt and ARC), whereas the individuals exploiting lentic and semi-lotic 
Table 4. Eigenvectors of morphological variables for axes 1 and 2 of the principal components analysis. The eigenvectors with the highest positive and negative values (in bold) were selected to interpret the species ordination in the multivariate morphological space. In the lower portion of the table are listed the eigenvalues and the percentage of variability explained by each principal component.

\begin{tabular}{lcc}
\hline Morphological variables & Axis 1 & Axis 2 \\
\hline Compression index & -0.012 & -0.211 \\
Depression index & 0.019 & 0.112 \\
Relative length of the caudal peduncle & 0.020 & -0.275 \\
Relative height of the caudal peduncle & -0.006 & $\mathbf{0 . 1 5 6}$ \\
Relative width of the caudal peduncle & -0.018 & $\mathbf{- 0 . 3 5 1}$ \\
Relative length of the head & -0.007 & -0.032 \\
Relative height of the head & -0.001 & -0.042 \\
Relative width of the head & -0.013 & -0.123 \\
Relative height of the mouth & -0.019 & $\mathbf{0 . 2 7 8}$ \\
Relative width of the mouth & -0.060 & 0.058 \\
Eye position & -0.003 & -0.129 \\
Relative area of the eye & $\mathbf{- 0 . 3 1 2}$ & -0.076 \\
Protrusion index & 0.001 & $\mathbf{0 . 1 5 1}$ \\
Relative area of the dorsal fin & $\mathbf{- 0 . 3 2 9}$ & -0.168 \\
Relative area of the caudal fin & -0.308 & -0.141 \\
Aspect ratio of the caudal fin & $\mathbf{0 . 2 8 6}$ & -0.006 \\
Relative area of the anal fin & $\mathbf{- 0 . 3 2 1}$ & $\mathbf{0 . 2 8 3}$ \\
Aspect ratio of the anal fin & $\mathbf{0 . 3 3 1}$ & -0.043 \\
Relative area of the pectoral fin & $\mathbf{- 0 . 3 3 2}$ & $\mathbf{- 0 . 3 1 4}$ \\
Aspect ratio of the pectoral fin & $\mathbf{0 . 3 1 1}$ & -0.144 \\
Relative area of the pelvic fin & -0.301 & $\mathbf{- 0 . 2 8 4}$ \\
Aspect ratio of the pelvic fin & $\mathbf{0 . 3 2 0}$ & $\mathbf{- 0 . 4 9 7}$ \\
\hline Eigenvalue & 33.65 & 9.35 \\
Predicted eigenvalue: broken-stick & 9.72 & 7.09 \\
Explained variability (\%) & 58.06 & 16.13 \\
Cumulative variability (\%) & 58.06 & 74.19 \\
\hline
\end{tabular}

habitats tended to have negative scores and showed larger pectoral, dorsal and anal fins, as well as larger eyes (Fig. 1a). This relationship between morphology and habitat was corroborated by the Mantel test performed at inter $(\mathrm{r}=0.42$, $\mathrm{p}<0.01)$ and intraspecific level $($ C. britskii: $\mathrm{r}=0.42, \mathrm{p}<0.01 ; S$. pappaterra: $\mathrm{r}=0.39 ; \mathrm{p}<0.01)$.

The axis 2 evidenced a segregation related to the morphological structures used to capture food items, revealing according to MRPP an ecomorphological segregation between $S$. pappaterra and $C$. britskii (A = $0.08 ; \mathrm{p}<0.01$ ). The first species, with negative scores, had higher values for the aspect ratio of the pelvic fin (ARPv), relative width of the caudal peduncle (RWPd), and relative areas of the pectoral and pelvic fins (RAPt and RAPv). On the other hand, $C$. britskii, with positive scores, had higher values for the relative areas of the anal fin (RAA), relative height of the mouth and peduncle (RHM and RHPd) and protrusion index (PI) (Fig. 1b; Fig. 2). The relationship between morphology and diet was corroborated by Mantel test performed at inter- $(\mathrm{r}=0.65 ; \mathrm{p}<0.01)$ and intraspecific level $(C$. britskii: $\mathrm{r}=0.72, \mathrm{p}<0.01 ;$ S. pappaterra: $\mathrm{r}=0.63$; $\mathrm{p}<0.01)$.

\section{Discussion}

Ecomorphology assumes that morphological attributes reflect important ecological characteristics, such as the use of resources, revealing the strategies adopted by the organisms and their adaptation to environmental conditions (Peres-Neto, 1999). In the present study, the hypothesis that differences in morphological patterns imply in different forms of resource exploitation was accepted, corroborating Oliveira et al. (2010) regarding the trend of the fish assemblage from the Upper Paraná River floodplain in establishing patterns of trophic and spatial niche exploitation according to ecomorphological adaptation of species. In addition, our results support the idea that morphology is a good predictor of the species ecology at inter- and intraspecific level. Thus such as reported by Oliveira et al. (2010), we found a significant correlation between morphology and spatial distribution at the interspecific level as well as the occurrence of two different ecomorphotypes: fish that exploit lotic and lower water habitats. However in the present study this trend was also registered within the same species. Thus the significant correlation between morphology and spatial distribution registered by the Mantel tests performed at intraspecific level evidenced that specimens collected in lotic habitats were morphologically more similar to each other than specimens from lentic habitats and vice versa.

According to the ordination along the ecomorphological multivariate space, both C. britskii and S. pappaterra collected in lotic habitats tended to have higher values of the aspect ratio of the anal, pelvic, pectoral, and caudal fins. These characteristics imply rapid progressive and retrograde movements, braking and continuous swimming, mainly in habitats with high current flow (Gatz Jr., 1979; Casatti \& Castro, 1998; Breda et al., 2005). On the other hand, individuals of both species found in lentic and semi-lotic habitats presented morphological traits (larger dorsal, anal and pectoral fins) that provide greater maneuverability and stabilization in deflections (Gatz Jr., 1979; Watson \& Balon, 1984; Breda et al., 2005). Maneuverability is defined as the ability of organisms to perform quick small-angled maneuvers (Webb et al., 1996). Thus, species with these characteristics exhibit a superior performance in the exploitation of structurally complex habitats with low current velocity (Oliveira et al., 2010; Chuang et al., 2006), such as connected and disconnected lagoons, where the presence of floating macrophyte stands contribute to increasing the environmental complexity. Conversely the intense sedimentation with predominance of mud and organic matter in the water column in these lentic habitats tend to promote a reduction in the mean value of water transparency (Thomaz et al., 2004), which may select those individuals with higher values of the eye area.

The second trend in the ecomorphological multivariate space was related to the feeding ecology. In this case it was recorded a morphological divergence between the species. Crenicichla britskii presented higher values of the relative height of the mouth and protrusion index. Such characteristics are associated with its ability to capture larger and evasive 

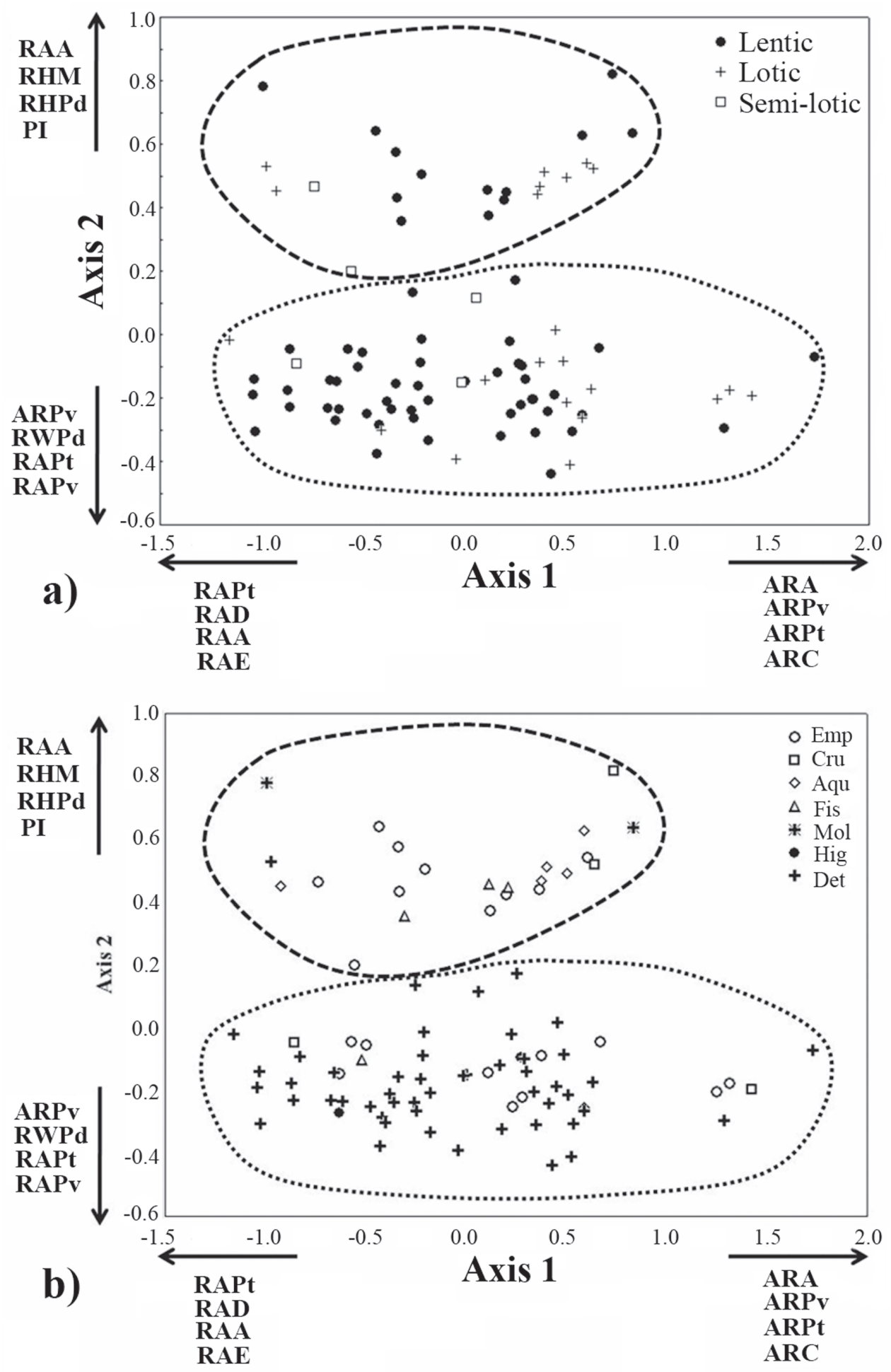

Fig. 1. Dispersion of the scores of the first two PCA axes, calculated with the variance matrix of 22 ecomorphological indices. a) Scores classified by the type of environment; b) Scores classified by food resources, where: Emp = empty, Cru = crustacean, $\mathrm{Aqu}=$ aquatic insect, $\mathrm{Fis}=$ fish, $\mathrm{Mol}=$ mollusk, Hig $=$ higher plant, Det $=$ detritus. Dashed line: Crenicichla britskii; dotted line: Satanoperca pappaterra. $\mathrm{ARA}=$ Aspect ratio of the anal fin; $\mathrm{ARC}=\mathrm{Aspect}$ ratio of the caudal fin; $\mathrm{ARPt}=\mathrm{Aspect}$ ratio of the pectoral fin; $\mathrm{ARPv}=\mathrm{Aspect}$ ratio of the pelvic fin; $\mathrm{PI}=$ Protrusion index; $\mathrm{RAA}=$ Relative area of the anal fin; $\mathrm{RAD}=$ Relative area of the dorsal fin; $\mathrm{RAE}=$ Relative area of the eye; $\mathrm{RAPt}=$ Relative area of the pectoral fin $; \mathrm{RAPv}=$ Relative area of the pelvic fin ; RHM = Relative height of the mouth; RHPd = Relative width of the caudal peduncle; RWPd = Relative width of the caudal peduncle. 

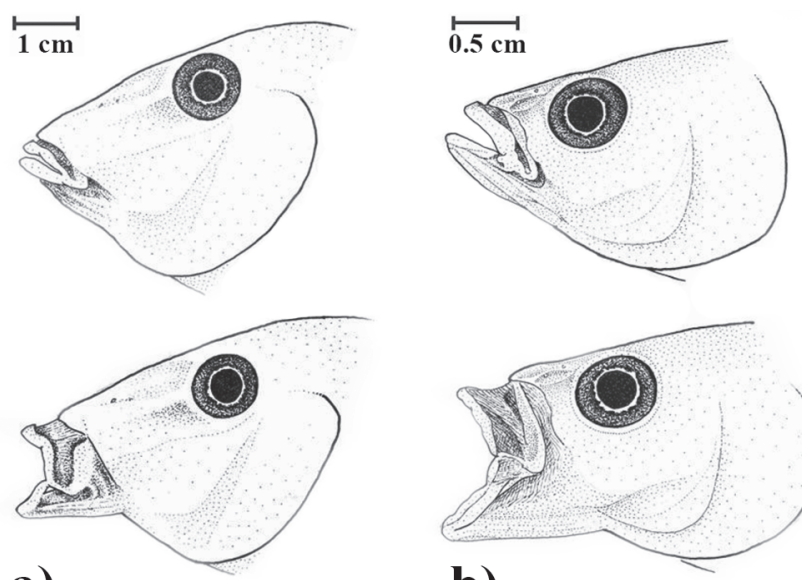

a)

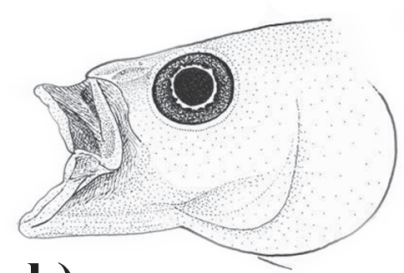

b)

Fig. 2. Head of Satanoperca pappaterra (a) and Crenicichla britskii (b), showing differences in the mouth protrusion.

preys throughout the water column (Hulsey \& García de León, 2005; Cochran-Biederman \& Winemiller, 2010), since the terminal position of the mouth and its higher protrusion (see Fig. 2) favor a wide oral aperture that enables a diet based on larger feeding items, such as crustacean, mollusk, fish and aquatic insect (Gibran et al., 2001; Casatti, 2002; Sampaio \& Goulart, 2011). Furthermore, this species also present a well-developed anal fin and a higher caudal peduncle, which are functionally related to the higher maneuverability, movement stabilization and start-ups at short distance displacements (Breda et al., 2005; Oliveira et al., 2010). These characteristics contribute to the impulsion of the fish during the early stage of the attack (Lauder \& Liem, 1981) and play an important role to perform sudden and interrupted displacements for the prey capture.

On the other hand, Satanoperca pappaterra has morphological traits (e.g. sub-terminal mouth and welldeveloped lips) that favor the capture of detritus and benthic invertebrates on the bottom, as recorded by Sampaio \& Goulart (2011). The present study revealed that this species can be considered a good swimmer, since it has wider caudal peduncle and well-developed pelvic and pectoral fins, which indicate higher abilities in stabilization, braking and accelerations (Gatz Jr., 1979; Watson \& Balon, 1984; Breda et al., 2005). According to Oliveira et al. (2010), well-developed caudal peduncles and pectoral fins are of paramount importance for benthic fish to stabilize the body on the substrate, as well as to start-ups at short distances displacements, which probably contributed to the feeding in the benthic region.

Although less clear than the interspecific variation in the ecomorphological space, individual divergences may also have an important role on the trophic niche occupation by both species. The significance of the Mantel test performed at intraspecific level evidenced that even subtle divergences in body shape are important to the capture of different food items, as evidenced by the consumption of aquatic insects by some specimens of $C$. britskii with higher values for the aspect-ratio of caudal, anal, pectoral and pelvic fins. This morphological design may favor a greater ability to swim (Breda et al., 2005) and capture aquatic insects along the water column or associated with submerged vegetation (Gibran et al., 2001). Therefore, such as the spatial dimension of the niche where the intraspecific morphological differentiation is related to the exploitation of habitats with distinct environmental conditions, trophic niche characteristics of each species are conditioned to its individual morphological variations. These results emphasize the need for recognizing the importance of differences within-species in studies of community ecology, which is rarely considered, especially in trait-based approaches encompassing Metazoan, where interspecific mean trait differences between co-occurring species are used to reveal structural patterns and community assembly processes, e.g. niche filtering and biotic interactions (Violle et al., 2012). Such approaches involving morphological diversity without any concern about intraspecific variations may be underestimating the real functional diversity exhibited by each species. According to Siefert (2012) intraspecific variation provides a more complete view of community structure patterns and processes driving their arrangement. Thus, as reported in our study, intraspecific variation in a range of individual traits determines resource-specific efficiency and preferences (Bolnick et al., 2003), being an indicative of the niche breadth occupied by the species (Van Valen, 1965; Bolnick et al., 2007).

In the present study, the ecomorphological analysis evidenced that variations in resource use are related to the body shape. In this way, the ecomorphology proved to be an effective tool able to contribute to the knowledge about the ecology of the species and allowed the understanding of how organisms respond to environmental pressures, which demonstrates its high predictive nature. Moreover our study supports that analyses incorporating both intraspecific and interspecific morphological variations can contribute to a greater understanding about the ecological structure of fish assemblages by providing evidences on the niche characteristics of each species.

\section{Acknowledgments}

The authors are grateful to Norma Segatti Hahn, Milza Fedatto Abelha, Fabrício B. Teresa and to two anonymous referees for their valuable suggestions for the improvement of this manuscript; Fabio Teruo Mise and Gabriel Deprá for their help with statistical analysis and drawings of fish, respectively; PEA/Nupélia/UEM/PROEX for logistic support; A. L. A. Sampaio and J. P. A. Pagotto are grateful to Coordination of Improvement of Higher Education Personnel (CAPES/Ministry of Education, Brazil) for the scholarships. 


\section{Literature Cited}

Agostinho, A. A., L. M. Bini, L. C. Gomes, H. F. Júlio Jr, C. S. Pavanelli \& C. S. Agostinho. 2004. Fish Assemblages. Pp. 223246. In: Thomaz, S. M., A. A. Agostinho \& N. S. Hahn (Eds.). The upper Paraná River and its floodplain: physical aspects, ecology and conservation. Leiden, Backhuys Publishers.

Autodesk. 2004. AutoCAD: graphic computation. Version 2004. San Rafael, Autodesk Inc.

Binning, S. A \& L. J. Chapman. 2010. Is intraspecific variation in diet and morphology related to environmental gradients? Exploring Liem's paradox in a cichlid fish. Integrative Zoology, 5: 241-255.

Bolnick, D. I., R. Svanbäk, M. S. Araújo \& L. Persson. 2007. Comparative support for the niche variation hypothesis that more generalized populations also are more heterogeneous. Proceedings of the National Academy of Sciences of the United States of America, 104: 10075-10079.

Bolnick, D. I., R. Svanbäk, J. A. Fordyce, L. H. Yang, J. M. Davis, C. D. Hulsey \& M. L. Forister. 2003. The ecology of individuals: incidence and implications of individual specialization. The American Naturalists, 161: 1-28.

Bonetto, A. A. 1986. The Paraná River system. Pp. 541-555. In: Davies, B. R. \& K. F. Walker (Eds.). The ecology of river systems. The Hague, Dr. W. Junk Publishers.

Breda, L., E. F. Oliveira \& E. Goulart. 2005. Ecomorfologia de locomoção de peixes com enfoque para espécies neotropicais. Acta Scientiarum: Biological Sciences, 27: 371-381.

Casatti, L. 2002. Alimentação dos peixes em um riacho do parque estadual Morro do Diabo, bacia do alto rio Paraná, sudeste do Brasil. Biota Neotropica, 2: 1-14.

Casatti, L. \& R. M. C. Castro. 1998. A fish community of the São Francisco River headwater riffles, southeastern Brazil. Ichthyological Exploration of Freshwaters, 9: 229-242.

Casatti, L. \& R. M. C. Castro. 2006. Testing the ecomorphological hypothesis in a headwater riffles fish assemblage of the rio São Francisco, southeastern Brazil. Neotropical Ichthyology, 4: 203214.

Castro, R. M. C., L. Casatti, H. F. Santos, A. L. A. Melo, L. S. F. Martins, K. M. Ferreira, F. Z. Gibran, R. C. Benine, M. Carvalho, A. C. Ribeiro, T. X. Abreu, F. A. Bockmann, G. Z. Pelição, R. Stopiglia \& F. Langeani. 2004. Estrutura e composição da ictiofauna de riachos da bacia do rio Grande no Estado de São Paulo, sudeste do Brasil. Biota Neotropica, 4: 1-28.

Chuang. L. C., Y. S. Lin, \& S. H. Liang. 2006. Ecomorphological comparison and habitat preference of 2 Cyprinid Fishes, Varicorhinusbarbatulus and Candidiabarbatus, in Hapen Creek of Northern Taiwan. Zoological Studies, 45: 114-123.

Cochran-Biederman, J. L. \& K. O. Winemiller. 2010. Relationships among habitat, ecomorphology and diets of cichlids in the Bladen River, Belize. Environmental Biology of Fishes, 88: 143-152.

Delariva, R. L. \& A. A. Agostinho. 2001. Relationship between morphology and diets of six Neotropical Loricariids. Journal of Fish Biology, 58: 832-847.

Douglas M. E \& Matthews, W. J. 1992. Does morphology predict ecology? Hypothesis testing within a freshwater stream fish assemblage. Oikos, 65: 213-224.

Freire, A. G. \& A. A. Agostinho. 2001. Ecomorfologia de oito espécies dominantes da ictiofauna do reservatório de Itaipu (Paraná/ Brasil). Acta Limnologica Brasiliensia, 13: 1-9.

Gatz Jr., A. J. 1979. Ecological morphology of freshwater stream fishes. Tulane Studies in Zoology and Botany, 21: 91-124.
Gibran, F. Z., K. M. Ferreira, \& R. M. C. Castro. 2001. Diet of Crenicichlabritskii (Perciformes: Cichlidae) in a stream of rio Aguapeí Basin, upper rio Paraná system, southeastern Brazil. Biota Neotropica, 1: 1-5.

Gotelli, N. J. \& A. M. Ellison. 2004. A primer of ecological statistics. Massachusetts, Publishers Sunderland. 479p.

Graça, W. J. \& C. S. Pavanelli. 2007. Peixes da planície de inundação do alto rio Paraná e áreas adjacentes. Maringá, Eduem. 241p.

Griffen, B. D. \& Mosblack, H. 2011. Predicting diet and consumption rate differences between and within species using gut ecomorphology. Journal of Animal Ecology, 80: 854-863.

Hellawell, J. M. \& R. Abel. 1971. A rapid volumetric method for the analysis of the food of fishes. Journal of Fish Biology, 3: 29-37.

Hora, S. L. 1922. Structural modifications in the fish of mountain torrents. Records of the Indian Museum, 24: 31-61.

Hulsey, C. D. \& F. J. García de León. 2005. Cichlid jaw mechanics: linking morphology to feeding specialization. Functional Ecology, 19: 487-494.

Hyslop, E. J. 1980. Stomach contents analysis - a review of methods and their application. Journal of Fish Biology, 17: 411-429.

Jackson, D. A. 1993. Stopping rules in principal components analysis: a comparison of heuristical and statistical approaches. Ecology, 74: 2204-2214.

Kawakami, E. \& G. Vazzoler. 1980. Método gráfico e estimativa de índice alimentar aplicado no estudo de alimentação de peixes. Boletim do Instituto Oceanográfico de São Paulo, 29: 205-207.

Kerfoot Jr., J. R. \& J. F. Schaefer. 2006. Ecomorphology and habitat utilization of Cottus species. Environmental Biology of Fishes, 76: 1-13.

Kullander, S. O. 2003. Family Cichlidae. Pp. 605-654. In: Reis, R. E., S. O. Kullander \& C. J. Jr. Ferraris (Eds.). Check list of the freshwater fishes of South and Central America. Porto Alegre, Edipucrs.

Lauder, G. V. \& K. F. Liem. 1981. Prey capture by Luciocephalus pulcher: implications for models of jaw protrusion in teleost fishes. Environmental Biology of Fishes, 6: 257-268.

Lowe-McConnell, R. H. 1991. Ecology of cichlids in South American and African waters, excluding the African Great Lakes. Pp. 6085. In: M. H. A. Keenleyside (Ed.). Cichlid Fishes: Behaviour, ecology and evolution. London, Chapman \& Hall.

Maack, R. 1981. Geografia física do estado do Paraná. Rio de Janeiro, José Olympio, 450p.

Mccune, B. \& M. J. Mefford. 1999. PC-ORD: multivariate analysis of ecological data. Version 5, Gleneden Beach, MjM Software Design.

Meyer, A. 1993. Phylogenetic relationships and evolutionary processes in east African cichlid fishes. Trends in Ecology \& Evolution, 8: 279-284.

Mittelbach, G. G., C. W. Osenberg \& P. C. Wainwright. 1992. Variation in resource abundance affects diet and feeding morphology in the pumpkinseed sunfish (Lepomis gibbosus). Oecologia, 90: 8-13.

Motta, P. J., S. F. Norton \& J. J. Luczkovich. 1995. Perspective on the ecomorphology of bony fishes. Environmental Biology of Fishes, 44: 23-33.

Montaña, C. G. \& K. O. Winemiller. 2009. Comparative feeding ecology and habitats use of Crenicichla species (Perciformes: Cichlidae) in a Venezuelan floodplain river. Neotropical Ichthyology, 7: 267-274.

Norton, S. F. 1995. A functional approach to ecomorphological patterns of feeding in cottid fishes. Environmental Biology of Fishes, 44: 37-60. 
Norton, S. F. \& E. L. Brainerd. 1993. Convergence in the feeding mode of ecomorphologically similar species in the Centrarchidae and Cichlidae. Journal of Experimental Biology, 176: 11-29.

Oliveira, E. F., E. Goulart, L. Breda, C. V. Minte-Vera, L. R. S. Paiva \& M. R. Vismara. 2010. Ecomorphological patterns of the fish assemblage in a tropical floodplain: effects of trophic, spatial and phylogenetic structures. Neotropical Ichthyology, 8: 569-586.

Pagotto, J. P. A., E. Goulart, E. F. Oliveira \& C. B. Yamamura. 2011. Trophic ecomorphology of Siluriformes (Pisces, Osteichthyes) from a tropical stream. Brazilian Journal of Biology, 71: 469-479.

Peres-Neto, P. R. 1999. Alguns métodos e estudos em ecomorfologia de peixes de riachos. Pp. 209-236. In: Caramaschi, E. P., R. Mazzoni \& P. R. Peres-Neto (Eds.). Ecologia de peixes de riachos. Série Oecologia Brasiliensis, vol. VI. Rio de Janeiro, PPGE-UFRJ.

Peterson, M. S. \& S. J. Vanderkooy. 1996. Preservation-induced changes in morphometrics of fishes: influence on prey sizechoice in juvenile walleye, Stizostedionvitreum (Mitchill). Ecology of Freshwater Fish, 5: 133-139.

Ricklefs, R. E \& D. B. Miles. 1994. Ecological and evolutionary inferences from morphology: an ecological perspective. Pp. 1341. In: Wainwright, P. C. \& S. M. Reilly (Eds.). Ecological morphology: integrative organismal biology. Chicago, The University of Chicago Press.

Sampaio, A. L. A. \& E. Goulart. 2011. Ciclídeos neotropicais: ecomorfologia trófica. Oecologia Australis, 15: 775-798.

Siefert, A. 2012. Incorporating intraspecific variation in tests of trait-based community assembly. Oecologia, 170: 767-775.

Swanson, B. O., A. C., Gibb, J. C. Marks \& D. A. Hendrickson. 2003. Trophic polymorphism and behavioral differences decrease intraspecific competition in a Cichlid, Herichthys minckleyi. Ecology, 84: 1441-1446.

Thomaz, S. M., T. A. Pagioro, L. M. Bini, M. C. Roberto \& R. R. A. Rocha. 2004. Limnological characterization of the aquatic environments and the influence of hydrometric levels. Pp. 75102. In: Thomaz, S. M., A. A. Agostinho \& N. S. Hahn (Eds.). The Upper Paraná River and its Floodplain: physical aspects, ecology and conservation. Leiden, Backhuys Publishers.
Van Valen, L. 1965. Morphological variation and width of ecological niche. The American Naturalist, 99: 377-390.

Wainwright, P. C. \& B. A. Richard. 1995. Predicting patterns of prey use from morphology of fishes. Environmental Biology of Fishes, 44: 97-113.

Watson, D. J. \& E. K. Balon. 1984. Ecomorphological analysis of fish taxocenes in rainforest streams of northern Borneo. Journal of Fish Biology, 25: 371-384.

Webb, P. W., G. D. Laliberte \& A. J. Schrank. 1996. Does body and fin form affect the maneuverability of fish traversing vertical and horizontal slits? Environmental Biology of Fishes, 46: 7-14.

Wikramanayake, E. D. 1990. Ecomorphology and biogeography of a tropical stream fish assemblage: evolution of assemblage structure. Ecology, 71: 1756-1764.

Winemiller, K. O. 1991. Ecomorphological diversification in lowland freshwater fish assemblages from five biotic regions. Ecological Monographs, 61: 343-365.

Winemiller, K. O., L. C. Kelso-Winemiller \& A. L. Brenkert. 1995. Ecomorphological diversification and convergence in fluvial cichlid fishes. Environmental Biology of Fishes, 44: 235-261.

Valentin, J. L. 1995. Agrupamento e ordenação. Pp. 25-55. In: PeresNeto, P. N., J. L. Valentin \& F. A. S. Fernandez (Eds.). Tópicos em tratamento de dados biológicos. Oecologia Brasiliensis, V. II, Rio de Janeiro, PPGE-UFRJ.

Violle, C., B. J. Enquist, B. J. McGill, L. Jiang, C. H. Albert, C. Hulshof, V. Jung \& J. Messier. 2012. The return of the variance: intraspecific variability in community ecology. Trends in Ecology and Evolution, 27: 244-252.

Xie, S., Y. Cui \& Z. Li. 2001. Dietary-morphological relationships of fishes in Liangzi Lake, China. Journal of Fish Biology, 58: 1714-1729.

Submitted April 27, 2012

Accepted February 14, 2013 by Fabricio Barreto Teresa Published June 28, 2013 